\begin{tabular}{|c|c|c|}
\hline & This Journal is available in Telkom University online Journals & 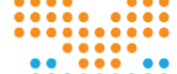 \\
\hline & Jurnal Manajemen Indonesia & \\
\hline Telkom & Journal homepage: journals.telkomuniversity.ac.id/ijm & $\begin{array}{l}\text { JURNAL } \\
\text { MANAEMEN } \\
\text { INDONESIA }\end{array}$ \\
\hline
\end{tabular}

\title{
Effects of E-Marketing and Social Media Marketing on E-commerce Shopping Decisions
}

Donni Juni Priansa and Bethani Suryawardani

Marketing Management Department, Telkom University, Bandung, Indonesia

\begin{abstract}
This research analyzes marketing through electronic media and social media as well as purchasing decisions on e-commerce sites; testing whether marketing through electronic media affects shopping decisions on e-commerce sites; testing whether marketing through social media affects shopping decisions on e-commerce sites; and testing whether marketing through electronic media and social media marketing affects shopping decisions on ecommerce sites. This research method is quantitative with a survey approach. The research population is ecommerce consumers in the city of Bandung. The sample size used was 125 samples. Path analysis is used as an analysis technique. The findings show that marketing through electronic media and social media and consumer decisions are in the high category. Marketing through electronic media affects consumer decisions to make purchases of 45.35\%; Marketing through social media affects consumer decisions to make a purchase of $35.73 \%$. In addition, marketing through electronic media and social media affect buying decisions of $81.08 \%$
\end{abstract}

Keywords: E-marketing, Social media marketing, Purchase decision.

\begin{abstract}
Abstrak
Penelitian ini menganalisis pemasaran melalui media elektronik dan media sosial serta keputusan pembelian di situs e-commerce; menguji apakah pemasaran melalui media elektronik memiliki efek terhadap keputusan berbelanja di situs e-commerce; menguji apakah pemasaran melalui media sosial memiliki efek terhadap keputusan berbelanja di situs e-commerce; serta menguji apakah pemasaran melalui media elektronik dan pemasaran media sosial memiliki efek terhadap keputusan berbelanja di situs $e$-commerce. Metode penelitian ini bersifat kuantitatif dengan pendekatan survei. Populasi penelitian merupakan konsumen e-commerce di Kota Bandung. Ukuran sampel yang digunakan adalah 125 sampel. Analisis jalur digunakan sebagai teknik analisis. Temuan menunjukkan pemasaran melalui media elektronik dan media sosial serta keputusan konsumen berada dalam kategori yang tinggi. Pemasaran melalui media elektronik memiliki efek terhadap keputusan konsumen untuk melakukan pembelian sebesar 45,35\%; Pemasaran melalui media sosial memiliki efek terhadap keputusan konsumen melakukan pembelian sebesar $35,73 \%$. Selain itu, pemasaran melalui media elektronik dan sosial media memiliki efek terhadap keputusan membeli sebesar $81,08 \%$.
\end{abstract}

Kata kunci: Pemasaran melalui media elektronik, pemasaran melalui media sosial, dan keputusan pembelian.

\section{INTRODUCTION}

There has been a significant increase in the number of Internet users worldwide. From We Are Social data in 2019 , there are 4.3 billion active Internet users globally and the number of Internet users continues to increase by $9.1 \%$ annually on average. This growth has had an impact upon the growth of mobile and social media users. Active social media users and mobile users amount to 3.4 billion and 3.2 billion users, respectively. Social media users via mobile grew by $10 \%$. Facebook continues to be the most popular social media platform with 2.2 billion users (wearesocial.com, 2019). 
In Indonesia, the e-commerce business reached 74 million consumers in 2015, which increased to 102 million users in 2016. Compared to other countries, the average Internet penetration in the Asia-Pacific region was $32 \%$ while Indonesia only achieved $29 \%$. Among the 74 million people who have access to e-commerce, only $7 \%$ participate in online transaction activities. Indonesian people have started to like shopping for expensive products on e-commerce sites (Noviandri, 2015).

Currently, the development of e-commerce businesses is strongly influenced by the e-marketing activities (Strauss and Frost, 2012) and social media marketing (Malita, 2011) conducted by e-commerce sites, considering that both strategies influence the attitudes and behaviors of consumers while shopping. E-commerce companies that utilize e-marketing and social media marketing strategies include Tokopedia, Shopee, Lazada, Zalora, Blibli.com, JD.id, Zilingo Shopping, and AliExpress (iPrice.co.id, 2018). However, the current study will only focus on Lazada, Zalora, and Tokopedia because these three e-commerce sites comprise different market segments, each with their own uniqueness. Lazada focuses on providing various consumer goods to meet every day needs, Zalora focuses on providing a variety of fashion products, and Tokopedia focuses on providing a diverse range of payment transaction tools.

This research was conducted in Bandung since it is a city wherein the number of e-commerce consumers continues to rise rapidly (iPrice.co.id, 2018). This research seeks to examine e-marketing, social media marketing, and e-commerce shopping decisions and determine the extent of the influence that e-marketing and social media marketing have on consumers' shopping decisions on e-commerce sites, both individually and together.

\section{LITERATURE REVIEW}

\section{A. Purchase Decision}

Consumers' online shopping habits can be gauged only with an understanding of their buying behavior. Engel et al. (2006) and Schifman and Kanuk (2012: 34) referred to consumer behavior as the behaviors involved in searching for, buying, utilizing, evaluating, and consuming products that consumers expect will meet their needs. Kotler and Armstrong (2012:177) stated that purchase decisions form a part of the buying decision process. In the final stage, consumers form preferences for various brands from a collection of available alternative choices as well as develop an intention to buy products they like.

Kotler and Armstrong (2012:183) explained that consumer decisions comprise five decisions, namely, choice of product, choice of brand, choice of distributor, choice of time of purchase, and choice about the quantity to be purchased; these five aspects are used to measure consumers' decision to shop online. These dimensions can be empirically measured and researched from e-commerce sites.

\section{B. E-Marketing}

E-marketing refers to marketing via electronic communication technology, specifically the Internet. The Internet is a physical network of various connected computers comprising server and communication networks that are used to store information and disseminate it (Chaffey, et al. 2013). Kotler and Armstrong (2012) described e-marketing as marketing using various online electronic media. Chen-Ling and Lie Ting (2006) and El-Gohary (2010) referred to e-marketing as marketing using web media and various related transaction activities that can be easily accessed by consumers.

Chen-Ling and Lie Ting (2006) stated that e-marketing comprised e-mail marketing, e-mail newsletters, viral e-mail, and banner ads; all four channels were examined in this study to empirically measure the effect of emarketing on e-commerce shopping decisions. Furthermore, they discussed that e-marketing is the process of marketing products and services to customers by utilizing various web media. E-marketing creates fundamental attitudes and behavioral changes in e-commerce consumers; thus, consumers who shop online are influenced by e-marketing. Therefore, our first research hypothesis (H1) is as follows: E-marketing influences buying decisions on e-commerce sites.

\section{Social Media Marketing}

According to Gurnelius and Susan (2011: 10), social media marketing refers to online publication that utilizes communication technology such as Web 2.0. It involves conversation, involvement, and participation. Evans and McKee (2011: 34) and Paramitha (2011) explained that social media transforms people from content readers into content publishers. This involves a change from the typical broadcast mechanism to a one-to-many 
model through conversation development. Ramadani et al. (2014) stated that social media marketing was a multi-channel media outlet that can influence the consumers' interest in making purchases.

Gurnelius and Susan (2011: 15) and Puntoadi (2011) found that the purpose of social media marketing is relationship building, brand development, promotion, publicity, and market research. Social media marketing is used as a product marketing tool and aims to strengthen brands.

Moreover, Gurnelius and Susan (2011: 15) observed that the most popular social media platforms are Instagram, Facebook, Twitter, WhatsApp, and Line; these are the five tools used in this study to empirically evaluate the consumers of e-commerce sites. Andersson and Ekman (2009), Keltner et al. (2014), Permatasari and Kuswadi (2017), and Permatasari and Laydi (2018) confirmed that social media marketing influences shopping decisions. Therefore, our second research hypothesis (H2) is as follows: Social media marketing influences buying decisions on e-commerce sites.

\section{RESEARCH METHODS}

This research is a descriptive verification study (Sarwono, 2008; Noor, 2011; and Sanusi, 2011). The descriptive research aspect involves describing the variables affecting e-marketing, social media marketing, and e-commerce shopping decisions, while the verification research aspect involves determining how e-marketing and social media marketing influence e-commerce shopping decisions. This research was designed to have a causal timeframe, which is limited to one point or is cross-sectional. (Sugiyono, 2016; Sudjana, 2012).

The sample population includes the e-commerce site customers in Bandung city, who use Lazada, Zalora, and Tokopedia but whose numbers are not known with certainty. Since the population size is not known with certainty, Malhotra (2011: 291) states that sample size can be determined by taking at least four or five times the number of statement items in the questionnaire. In this study, there are 25 statement items; hence, the study sample size is $25 \times 5=125$ consumers. However, in our implementation, we extended the sample size to 150 consumers, assuming that 25 respondents may be mistakenly included in the sample or that the questionnaire distributed may be unsuitable for processing. The research data were obtained using a Likert-scale choice of five alternative answers or scores ranging from 5 (largest) to 1 (smallest). Data collection was conducted using a questionnaire instrument (Sugiyono, 2016).

The descriptive analysis involved first converting the questionnaire results into quantitative data based on the weight of predetermined categories and then creating a general description of the respondents' responses to each variable, including statistical processing by reviewing the number, frequency, and standard deviations for each item and indicator, which were summarized into tabulations and graphs. Path analysis was used as the statistical data analysis technique.

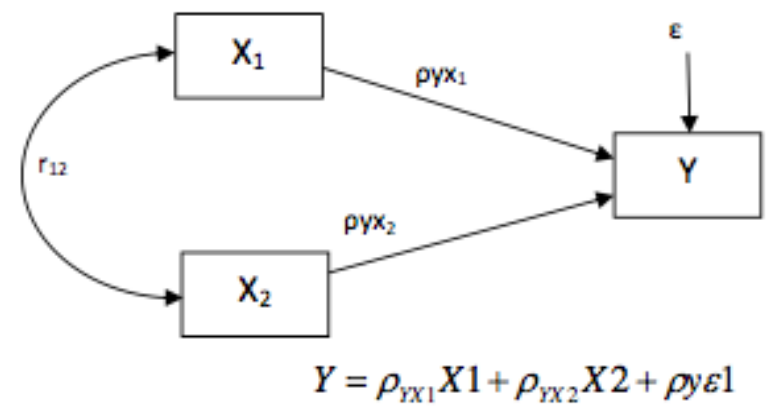

Figure 1. Path Analysis Model

\section{RESULTS AND DISCUSSION}

From the summary of results, the average e-marketing score was 4.07 , the average social media marketing score was 4.05, and the average shopping decision score was 4.09-all of which can be classifed as high scores. 


\section{A. Correlation Test Results}

There was significant correlation among all variables. The correlation test results indicate that the correlation between e-marketing (X1) and social media marketing (X2) was 0.660 (strong), e-marketing (X1) and shopping decisions (Y) was 0.832 (very strong), and social media marketing (X2) and shopping decisions (Y) was 0.946 (very strong)

\section{B. Significance Test Results}

The significance test results of the simultaneous influence of e-marketing and social media marketing on shopping decisions are shown in Table 1 . The results indicate that the $\mathrm{F}$ count was greater than the $\mathrm{F}$ value. The value of sig. was 0.00 , which is less than 0.05 ; thus, the hypothesis is proven.

Table 1. Simultaneous Hypothesis Test

\begin{tabular}{|rl|r|r|r|c|c|}
\hline \multicolumn{1}{|l|}{ Model } & \multicolumn{1}{|c|}{$\begin{array}{c}\text { Sum of } \\
\text { Squares }\end{array}$} & \multicolumn{1}{c|}{$\mathrm{df}$} & Mean Square & $\mathrm{F}$ & Sig. \\
\hline \multirow{2}{*}{1} & Regression & 967.198 & 2 & 483.599 & 66.348 & $.000^{\mathrm{b}}$ \\
& Residual & 889.234 & 122 & 7.289 & & \\
& Total & 1856.432 & 124 & & & \\
\hline
\end{tabular}

Source: Data Processing (2019)

The significance test results regarding the influence of e-marketing and social media marketing on shopping decisions on e-commerce sites are partially presented in Table 2.

Table 2. Partial Hypothesis Test

Coefficients $^{\mathrm{a}}$

\begin{tabular}{|c|c|c|c|c|c|}
\hline \multirow[t]{2}{*}{ Model } & \multicolumn{2}{|c|}{ Unstandardized Coefficients } & \multirow{2}{*}{$\begin{array}{c}\begin{array}{c}\text { Standardized } \\
\text { Coefficients }\end{array} \\
\text { Beta }\end{array}$} & \multirow[t]{2}{*}{$\mathrm{T}$} & \multirow[t]{2}{*}{ Sig. } \\
\hline & $\mathrm{B}$ & Std. Error & & & \\
\hline (Constant) & 9.597 & 2.416 & & 3.973 & .000 \\
\hline E- Marketing & .546 & .067 & .574 & 8.123 & .000 \\
\hline $\begin{array}{l}\text { Social media } \\
\text { Marketing }\end{array}$ & .499 & .064 & .483 & 7.780 & .000 \\
\hline
\end{tabular}

a. Dependent Variable: Keputusan Berbelanja

Source: Data Processing (2019)

The results indicate that the e-marketing had a significance value of 0.00 ; thus, ho is rejected. Its t-value is greater than the table value, thus, the correlation significance test conducted by using both, a significance value and a t-test, prove the acceptance of H1. Therefore, e-marketing has a positive and significant effect on shopping decisions on e-commerce sites. Social media marketing had a significance value of 0.00 and a t-value greater than the table value; hence, $\mathrm{H} 2$ accepted. The correlation significance test conducted by using both a significance value and a t-test, thus, social media marketing has a positive and significant effect on shopping decisions on e-commerce sites.

\section{Path Analysis}

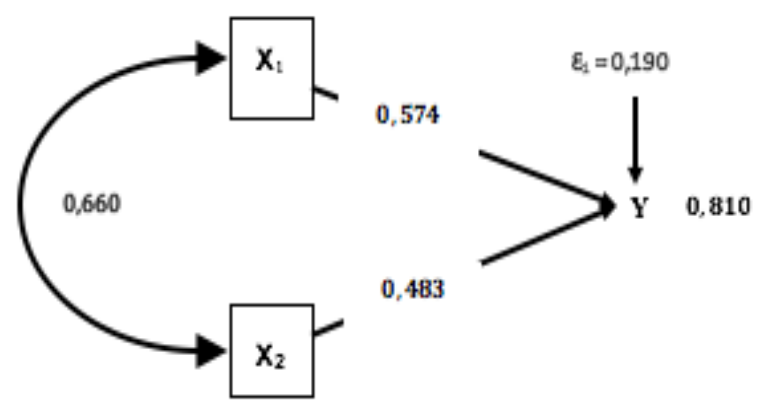

Figure 2. Path Analysis Results 
As per Figure 2, the results of the path analysis test are described in Table 3.

Table 3. Results for Path Model 1

\begin{tabular}{|l|c|}
\hline \multicolumn{1}{|c|}{ Variable } & Path Coefficient \\
\hline E- Marketing $\left(\mathrm{X}_{1}\right)$ & 0.574 \\
\hline Social Media Marketing $\left(\mathrm{X}_{2}\right)$ & 0.483 \\
\hline
\end{tabular}

Source: Data Processing (2019)

Thus, the path equation formula is given by: $\mathrm{Y}=0.574 . \mathrm{X}_{1}+0.483 . \mathrm{X}_{2}+\varepsilon$

The results of the path coefficient test are listed in Table 4.

Table 4. Total Results: Direct and Indirect Effects of Path Model 1

\begin{tabular}{|c|c|c|c|c|}
\hline \multirow{2}{*}{ Variable } & \multirow{2}{*}{ Direct Effect (\%) } & \multicolumn{2}{|c|}{ Indirect Effect } & \multirow{2}{*}{$\mathbf{R}^{\mathbf{2}} \mathbf{Y X 1 , Y X 2}$} \\
\cline { 3 - 4 } & & \multirow{2}{*}{$\mathbf{X}_{\mathbf{1}} \mathbf{( \% )}$} & $\mathbf{X}_{\mathbf{2}} \mathbf{( \% )}$ & \\
\hline$X_{1}$ & 32.95 & - & 12.4 & 45.35 \\
\hline$X_{2}$ & 23.33 & 12.4 & - & 35.73 \\
\hline $\mathbf{R}^{\mathbf{2}}$ & \multicolumn{3}{|r}{} & $\mathbf{8 1 . 0 8}$ \\
\hline
\end{tabular}

Source: Data Processing (2019)

\section{Direct Effects}

$\begin{array}{lll}\boldsymbol{\rho} Y X_{1(X)} \boldsymbol{\rho Y X}_{1} & = & \left(0.574_{(\mathrm{X})} 0.574\right)_{(\mathrm{X})} 100 \% \\ \boldsymbol{\rho} \mathrm{YX}_{2(\mathrm{X})} \boldsymbol{\rho} \mathrm{YX}_{2} & = & \left(0.483_{(\mathrm{X})} 0.483\right)_{(\mathrm{X})} 100 \%\end{array}$

\section{Indirect Effects}

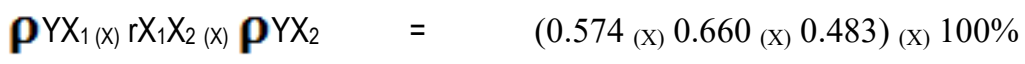

$$
\begin{aligned}
& \boldsymbol{\rho Y Y X}_{2(\mathrm{X})} \mathrm{rX}_{2} \mathrm{X}_{1(\mathrm{X})} \boldsymbol{\rho} \mathrm{YX}_{1}=\quad\left(0.483_{(\mathrm{X})} 0.660_{(\mathrm{X})} 0.574\right)_{(\mathrm{X})} 100 \%
\end{aligned}
$$

The total influence of e-marketing on shopping decisions amounted to $45.35 \%$, with $32.95 \%$ arising from the direct effect of e-marketing and $12.4 \%$ from the indirect effect of social media marketing. The total impact of social media marketing on shopping decisions amounted to $35.73 \%$, with $23.33 \%$ arising from the direct influence of social media marketing and $12.4 \%$ arising from the indirect influence of e-marketing. Thus, the combined effect of e-marketing and social media marketing on shopping decisions, amounts to $81.08 \%$.

\section{Determination Test Results}

Table 5. Output Determination Coefficient

Model Summary ${ }^{\mathrm{b}}$

\begin{tabular}{|l|r|r|r|c|}
\hline Model & \multicolumn{1}{|c|}{$\mathrm{R}$} & $\mathrm{R}$ Square & $\begin{array}{c}\text { Adjusted R } \\
\text { Square }\end{array}$ & $\begin{array}{c}\text { Std. Error of the } \\
\text { Estimate }\end{array}$ \\
\hline 1 & $.900^{\mathrm{a}}$ & .810 & .813 & 2.700 \\
\hline
\end{tabular}

a. Predictors: (Constant), Social Media Marketing, E- Marketing

b. Dependent Variable: Shopping Decision

Source: Data Processing (2019)

Table 5 shows that the coefficient of determination $\left(\mathrm{R}^{2}\right)$ is 0.810 . This value shows that e-marketing and social media marketing simultaneously influence $81.0 \%$ of shopping decisions, while the remaining $19.0 \%$ is 
influenced by other factors not discussed in this study, such as sales promotion, brand image, etc. Based on the influence classification guidelines, presented in Table 5, the magnitude of these simultaneous effects can be classified as very strong.

These results indicate that both e-marketing and social media marketing have a positive and significant effect on consumers' decisions to shop on e-commerce sites, especially Lazada, Zalora, and Tokopedia. These online shopping sites use e-mail marketing, e-mail newsletters, viral e-mail, and banner ads as strategies to encourage consumers to shop. These strategies are implemented regularly by Lazada, Zalora, and Tokopedia so that consumers have adequate information to support their purchasing decisions. Meanwhile, the social media marketing activities are regularly conducted by Lazada, Zalora, and Tokopedia via Instagram, Facebook, Twitter, WhatsApp, and Line. These five social media sites are used to inform consumers about various offers and discounts that can influence them to shop on e-commerce sites.

\section{CONCLUSION}

The hypothesis testing results indicate that e-marketing, social media marketing, and consumer e-commerce shopping decisions belong to the high classification. E-marketing affects consumers' e-commerce shopping decisions, both positively and significantly. The total contribution of e-marketing's influence on consumers' decisions to shop on e-commerce sites, was $45.35 \%$. Similarly, social media marketing also influences consumers' e-commerce shopping decisions, both positively and significantly. The total contribution regarding social media marketing's influence on consumer decisions to shop on e-commerce sites was $35.73 \%$. Thus, emarketing and social media marketing together influence consumer decisions to shop on e-commerce sites, both positively and significantly, with a combined contribution of $81.08 \%$. Thus, the management of Lazada, Zalora, and Tokopedia must maintain and increase the frequency of marketing activities via e-marketing and social media marketing.

\section{REFERENCES}

Andersson, M., \& Ekman, P. (2009). Ambassador Networks and Place Branding. Journal of Place Management and Development, 2(1), 41-51.

Chaffey, D., Mayer, R., Johnston, K., \& Ellis-Chadwick, F. (2013). Internet Marketing: Strategy, Implementation and Practice. United Kingdom: Pearson Education Limited.

El-Gohary. (2010). Factors Affecting E-Marketing Adoption and Implementation in Tourism Firms: An Empirical Investigation of Egyptian Small Tourism Organisations. Tour Management, 33(5), 1256-1269.

Engel, J. F., Blackwell, G., \& Miniard, P. W. (2006). Perilaku Konsumen. Jakarta: Binarupa Aksara.

Evans and McKee. (2011). Social Media Marketing The Next Generation of Business Engagement. Canada: Wiley Publishing Inc.

Fang, C. L., \& Lie, T. (2006). Assessment of internet marketing and competitive strategies for leisure farming industry in Taiwan. Journal of American Academy of Business, 8(2), 296-300.

Gurnelius, \& Susan. (2011). 30-minute Sosial Media Marketing. USA: McGraw-Hill Companies.

Iprice.co.id.(2018).The Map of E-Commerce in Indonesia.Retrieved from https://iprice.co.id/insights/mapofecommerce/en/. Accessed 10 December 2018

Keltner, D., Kogan, A., Piff, P. K., \& Saturn, S. R. (2014). The sociocultural appraisals, values, and emotions (SAVE) framework of prosociality: Core processes from gene to meme. Annual review of psychology, 65, 425-460.

Kotler, P., \& Armstrong, G. (2012). Principles of Marketing. New Jersey: Prentice Hall.

Malhotra, N. K., \& David F. B. (2011). Marketing Research: An Applied Orientation. England: Pearson Publishing.

Malita, L. (2011). Social Media Time Management Tolls dan Tips. Procedia Computer Science, 3, 747-753.

Noor, J. (2011). Metode Penelitian. Jakarta: PT Bhuana Ilmu Populer.

Noviandri, L. (2015). Statistik Pengguna Internet dan Media Sosial Terbaru 2015. Retrieved from 18 Agustus 2015. Dapat diakses di https://id.techinasia.com/talk/statistik-pengguna-internet-dan-media-sosialterbaru-2015/, accessed 18 Agustus 2015.

Paramitha, C. R. P. (2011). Analisis Faktor Pengaruh Promosi Berbasis Sosial Media terhadap Keputusan 
Pembelian Pelanggan dalam Bidang Kuliner. Semarang: Tesis UNDIP.

Permatasari, A., \& Kuswadi, E. (2017). The Impact of Social Media on Consumers' Purchase Intention: A Study of Ecommerce Sites in Jakarta-Indonesia. Review of Integrative Business and Economics Research, 6 , 321.

Permatasari, A., \& Laydi, F. (2018). The Effects of Social Media Advertising on Consumer Purchase Intention: A Case Study of Indonesian Family Start-Up Enterprises. International Journal of Technology Transfer and Commercialisation, 16(2), 159-172.

Puntoadi, D. (2011). Menciptakan Penjualan Melalui Social Media. Jakarta: PT Elex Komputindo.

Ramadani, V., Demiri, A., \& Saiti-Demiri, S. (2014). Social Media Channels: the Factors that Influence the Behavioural Intention of Customers. International Journal of Business and Globalisation, 12(3), 297314.

Sanusi, A. (2011). Metode Penelitian Bisnis. Jakarta: Salemba Empat.

Sarwono, J. (2008). Metode Penelitian Kuantitatif dan Kualitatif. Yogyakarta: PT. Graha Ilmu.

Schiffman, L.G., \& Kanuk. (2012). Consumer Behaviour. New Jersey: Prentice Hall.

Strauss, J., \& Raymond, F. (2012). E-Marketing. London: Pearson.

Sudjana. (2012). Metode Statistika. Bandung: Tarsito.

Sugiyono. (2016). Metode Penelitian Bisnis. Bandung: CV. Alfabeta.

We Are Social. (2019). Digital 2019: Global Internet Use Accelerates. Retrieved from https://wearesocial.com/blog/2019/01/digital-2019-global-internet-use-accelerates. Accessed 14 Agustus 2019.

Wijaya, K. K. (2015). "Berapa Jumlah Pengguna Website, Mobile, dan MEDIA SOSIAL DI INDONESIA?" Retrieved from https://id.techinasia.com/laporan- pengguna-website-mobile-media-sosial-indonesia/, accessed 21 January 2015. 